\title{
Istanbul 2010
}

\author{
By Gönül Dönmez-Colin
}

Fall 2010 Issue of KINEMA

\section{9th ISTANBUL INTERNATIONAL FILM FESTIVAL 2010}

The Istanbul International Film Festival, the largest of its kind in the country, has enriched its repertoire this year with 200 films under twenty-three categories ranging from the prestigious products of 2009 and recent films of 2010 to all time classics. Concentrated largely around the Beyoğlu quarter, where the Turkish national cinema was born, the festival stretched over two weeks, with the second week specially designed for the foreign guests. This year the foreigners had a chance to explore the magnificent city, the Cultural Capital of Europe for 2010, even longer, when the eruption of the Eyjafjallajokul volcano in Iceland paralyzed most European air traffic for several days.

The opening film was the melodrama Le concert (The Concert) by Radu Mihaileanu, a France-Italy-Romania and Belgium co-production that explored the issue of identity through classical music. Among the eleven films in competition, chosen for their relation to some art form, Johann Sfar's Gainsbourg (Vie héroïque) (Gainsbourg, France-USA) about the legendary bad boy of the French music scene during a good part of the latter half of the twentieth century drew large crowds. Father of actress-singer Charlotte Gainsbourg and lover of many beautiful women, including Brigitte Bardot, in addition to Charlotte's mother Jane Birkin, Gainsbourg was interpreted by Eric Elmosnino. The role of Brigitte Bardot was given to the Corsican actress Laetitia Casta.

Taiwanese Tsai Ming-liang's Visage (Face), shot in the Louvre museum in Paris, a film within a film about Salome and a bereaved director, carried all the familiar aspects of Tsai's style to the unfamiliar surroundings. The choice of the International jury, headed by the legendary Austrian actor Klaus Maria Brandauer, for the Golden Tulip was De helaasheid der dingen (The Misfortunates, Belgium) by Felix Van Groeningen, an energetic look at the pains of growing up, development of individuality and the power of art, rendered with precise and sensible details.

The Human Rights Section competition included The Son of Babylon by Mohamed al-Daradji (Iraq-UKFrance-Palestine-Holland-UAE-Egypt) about the need to grieve and forgive when the wounds of Saddam's Iraq are still open; Ajami (Israel-Germany) by the Israeli and Palestinian directing duo, Yaron Shani and Scandar Copti), one of the most successful films of the year in Israel and Tony Gatlif's Korkoro (Freedom, France), about the persecution of the gypsies by the Nazis, which had already won the Grand Prix and Audience Prizes at the Montreal World Film Festival 2009.

The main attraction for most foreign guests, particularly the festival programmers, are the Turkish Cinema sections. The national cinema has reached its peak in the 2000s, winning top awards at prestigious festivals, including the Golden Bear at the Berlin Film Festival 2010 for Bal (Honey) by Semih Kaplanoğlu.

The commercial production surpasses Hollywood at the box office and the middle-of-the-road filmmakers catch both the festival and distribution circuits. Only in France last year, most major film festivals organized panoramas of Turkish cinema, and other countries have been following suit. The next in line is Poland's Era New Horizon Film Festival that is preparing a large publication in Polish in addition to including new Turkish films in their main programmes.

A specific problem with the Istanbul Film Festival is that it arrives too late in the season: several of the films in competition have already done the festival circuits. For example, Karanliktakiler (In Darkness) by Çağan Irmak and Büyük Oyun (A Step into Darkness) by Atıl İnaç were screened at the Montreal World Film Festival, and a few others have participated in national festivals as well (Antalya, Adana, Ankara, Bursa) and/or have been released commercially, whereas internationally acclaimed filmmakers like Nuri Bilge Ceylan wait for prestigious festivals of the West (Cannes, Berlin, Venice) for their world premiere. The situation makes it difficult for foreign festival programmers to unearth precious gems and for the journalists of major trade papers to locate 'new' films to review. Nonetheless, for the lovers of cinema, including critics, researchers and film historians not having such worries, it is a pleasure to relax and watch the crop of the 
year. They can compare and contrast, exchange opinions with other festival goers (who seem to be very passionate about cinema) and even catch a filmmaker or two to chat between the screenings over a glass of beer offered free by some sponsors.

The best Turkish film of the festival in my opinion was $B a l$, an incredible voyage to the soul employing what Kaplanoğlu defines as 'spiritual realism'. The final scene when the little boy almost becomes one with the gigantic trunk of a timeless tree is to rest in memory for a very long time. On the other hand, Vavien by Yağmur and Durul Taylan, awarded by both the major Jury and FIPRESCI prizes, well made, but more in the commercial style of the brothers begs the question of why FIPRESCI, which is the 'critics' eye' would award it. Kıskanmak (Envy) by Zeki Demirkubuz, a languid and sensual rendition of a Turkish Madame Bovary story well placed in its epoch and its geo-politics, was eschewed for some unknown reasons. Kosmos by Reha Erdem, the latest genius of Turkish cinema, especially with his previous Hayat Var (My Only Sunshine), was shown out of competition, but could have been an excellent candidate if it were in competition. Shot in the Kars province, forgotten by time and history (recently discovered thanks to a now defunct festival that was held there for some years), the film is about a timeless and space-less character named Kosmos, who arrives from nowhere and wins the hearts of the villagers, frozen in time, with his so-called healing powers while robbing them of their worldly belongings.

The recent documentary boom in Turkey, initiated particularly by women and ethnic minorities (specifically Kurds) has born fruit with over twenty documentary entries. With the so-called 'opening-up' policy of the government, the long taboo subjects such as the 1938 massacre of Kurds in Dersim (re-named Tunceli) has become the subject of several documentaries as a symbol of the perpetual suffering of the Kurdish people. Bertij by Caner Canerik and İki tutam saç (Two Locks of Hair: The Missing Girls of Dersim) by Nezahat Gündoğan on this subject and Taşlaşan vicdanlar (Brutal Consciences) by Cenk Örtülü and Zeynel Koç about the alleged ill-treatment of Kurdish children in the name of Terrorism Prevention Act were impressive works.

Some of the other noteworthy sections of the festival were From the World Film Festivals: Challenging the Years (the latest films of Patrice Chéreau, Werner Herzog, Alain Resnais and Jacques Rivette); Young Masters: Mined Zone with Ruzhaye Sabz (Green Days) by Hana Makhmalbaf, Zanan-e Bedun-e Mardan (Women Without Men) by Shirin Neshat et al; Kids Menu; and Istanbul Inside and Outside. The festival programme also included retrospectives on the Palestinian filmmaker Elia Suleiman and the British filmmaker Joseph Losey and a panorama of North African and Middle Eastern films.

The closing film of the festival was Mother and Child by Rodrigo García (USA). The son of Nobel laureate Gabriel García Márquez, García elevates the mother and daughter relations to a mythical status in a drama that follows the intersecting lives of three women: a fifty year old, her daughter she gave up for adoption thirty-five years ago and a woman in her twenties looking to adopt a baby.

\section{References}

\section{AWARDS}

International Golden Tulip Competition

De helaasheid der dingen (The Misfortunates, Belgium) by Felix Van Groeningen

Special Jury Prize

Sandrine Kiberlaine for her role in Mademoiselle Chambon (France) by Stéphane Brizé

\section{National Golden Tulip Competition}

Best Film

Vavien by Yamur and Durul Taylan

Best director

Miraz Bezar for Min Dit (The Children of Diyarbakır)

Best Actor

Şenay Orak for her role in The Children of Diyarbakır 
Best Actor

Tansu Biçer for his role in Beş Şehir (Five Cities)

Best Screenplay

Engin Günaydın for Vavien

Best Director of Photography

Bariş Özbiçer for Bal (Honey)

Best Music

Mustafa Biber for The Children of Diyarbaktr

Special Prize of the Jury

Bal (Honey) by Semih Kaplanoğlu

\section{Other awards}

Council of Europe Film Award 'FACE'

Ajami by Scandar Copti and Yaron Shani Israel-Germany)

Special Jury Prize

The Day God Walked Away by Philippe van Leeuw (France-Belgium)

\section{International Film Critics (FIPRESCI) Award}

International Competition

Mademoiselle Chambon by Stéphane Brizé

National Competition

Vavien by Yă̆mur and Durul Taylan

People's Choice Awards

J'ai tué ma mére (I Killed My Mother) by Xavier Dolan (Canada, international competition)

Bal (Honey) by Semih Kaplanoğlu (national competition)

\section{Author Information}

Gönül DÖNMEZ-COLIN is an independent researcher and writer whose publications include Women, Islam and Cinema, Cinemas of the Other: A personal Journey with Filmmakers from the Middle East and Central Asia, Cinema of North Africa and the Middle East (ed.); Turkish Cinema: Identity, Distance and Belonging (Reaktion Books), and Routledge Dictionary of Turkish Cinema (2014). 